\title{
Pasientinformasjon i pakningsvedlegg
}

Myndighetene har i mange år vært opptatt av at legemidler skal være utstyrt med forsvarlig informasjon. I 1938 kom det en bestemmelse om at de skulle ha pakningsvedlegg som beskrev produktets innhold og virkemåte (1). Nytt det siste tiåret er at informasjon om virkninger og bivirkninger også skal være tilgjengelig for brukerne $i$ et enkelt og forståelig språk. Legemiddelforskriften angir at lesbarheten skal testes i samarbeid med en målgruppe pasienter «for å sikre at teksten er lett leselig, klar og brukervennlig» (2, § 3-52). Legemiddelprodusenten har krav på seg til å vedlegge resultat av slike tester til søknaden om markedsføringstillatelse (2).

Pakningsvedlegg har vi altså, men blir de lest? En dansk studie viser at $70 \%$ av pasientene alltid leser dem, $15 \%$ leser dem ofte (3). Pasientene er mest interessert $\mathrm{i}$ å lese om medikamenters bivirkninger (77\%), virkninger, bruk og oppbevaring (50-30\%). Men at pakningsvedleggene leses, er ikke ensbetydende med at innholdet blir forstått. Hele $38 \%$ av pasientene har problemer med å lese og forstå teksten (3).

I dette nummer av Tidsskriftet forfølger Janne Guldteig Storflor og medarbeidere disse spørsmålene (4). De har systematisk tatt for seg teksten i pakningsvedleggene for 17 av de 25 mest brukte virkestoffene i medikamenter på det norske markedet. Ordningen med likeverdig bytte av legemidler (synonympreparatordningen) av 2001 gjør at pasientene kan få en rekke ulike produsenters virkestoffer på samme resept. Det gjør en slik undersøkelse ekstra viktig. De finner til dels betydelige forskjeller i omtaler av indikasjoner, kontraindikasjoner, forsiktighetsregler, interaksjoner - og særlig bivirkninger - mellom pakningsvedlegg for ett og samme virkestoff. Når det gjelder indikasjoner, inneholder vedleggene generelt for mye og for vanskelig tolkbar informasjon. I interaksjonsdelen kan legemiddelgrupper angis uten at de forklares ytterligere. Det er lett å anta, med forfatterne, at de færreste pasienter kan avgjøre om et legemiddel hører inn under «dikumarolgruppen» eller «orale resiner». Burde slik informasjon vært forbeholdt legen?

En viktig begrunnelse for innføringen av kravet er pasientsikkerheten. Det antas at informerte pasienter har økt etterlevelse og at pasientsikkerheten fremmes ved riktig, trygg og effektiv bruk av legemidler. Imidlertid kan uklar eller uriktig informasjon gi usikre, tvilende, engstelige og urolige pasienter - noe som trolig ikke bedrer sikkerheten. Det er bivirkningene pasientene vektlegger når de leser pakningsvedlegg (3). Jeg har hørt utsagn som «Når du leser om alle bivirkningene, så tør du knapt ta medisinene», «Jeg lot være å starte med medisinen du ga meg etter at jeg leste om alle bivirkningene». Storflor og medarbeidere fant at det $\mathrm{i}$ to av fire pakningsvedlegg for ibuprofen ble omtalt åtte bivirkninger, i de to andre ble det omtalt henholdsvis 32 og 44 bivirkninger. For en pasient vil et legemiddel med 44 bivirkninger fremstå som farligere enn et synonymt preparat der kun åtte oppgis. Tilsvarende vil et legemiddel der alvorlige bivirkninger som hjerteinfarkt, slag og død oppgis, fremstå som farligere enn et synonympreparat der disse ikke er nevnt. I den refererte danske undersøkelsen oppga $32 \%$ av pasientene at de hadde unnlatt å ta forskrevet legemiddel på grunnlag av bivirkninger omtalt i pakningsvedlegget (3).

Pakningsvedlegg må skille bedre mellom vanlige bivirkninger og svært sjeldne bivirkninger. Hyppighet og statistikk er vrient nok for leger, sannsynligvis er det enda vanskeligere for deres pasienter. Endres pakningsvedleggene, kan de bli et gode - ikke en produsent av ytterligere bivirkninger. Legemiddelmyndigheter både i Norge og EU/EØS-området ønsker å gjennomgå tekstene i pakningsvedlegg slik at informasjonen samordnes. Her er det viktig at godkjennende legemiddelmyndighet må ha siste ord, ikke legemiddelprodusentene.

Brukerne skal bidra ved utforming og testing av pakningsvedlegg (2). Vi vet lite om disse prosessene. Er de godt nok gjennomført? Storflor og medarbeidere dokumenterer at brukernes synspunkter ikke er godt nok ivaretatt i utformingen av dagens pakningsvedlegg. Legemiddelmyndighetene bør få drahjelp av brukerorganisasjoner til å lage bedre pakningsvedlegg til de mest brukte legemiddelpreparatene på det norske markedet. Oppgaven med en slik gjennomgang er overkommelig. Generelt er det for mye tekst i pakningsvedlegg. Noen har hevdet at «less is more» (5). Brukerne bør bestemme om det er riktig.

\section{Harald Reiso}

harald.reiso@medisin.uio.no

Harald Reiso (f. 1955) er dr.med., spesialist i allmennmedisin og samfunnsmedisin og fastlege/kommuneoverlege i Arendal kommune. Forfatter har fylt ut ICMJE-skjemaet og oppgir ingen interessekonflikter.

Litteratur

1. Horwitz A, Reuther L, Andersen SE. Patienters vurdering af medicinpakningernes indlægssedler. Ugeskr Læger 2009; 171: 599-602.

2. Ot.prp. nr. 50 (1938). Om lov om innførsel av apotekvarer og gifter samt om handel med gifter, farmasøitiske spesialpreparater mv.

3. FOR 2009-12-18 nr. 1839: Forskrift om legemidler (legemiddelforskriften). www.lovdata.no/for/sf/ho/xo-20091218-1839.html (10.4.2013)

4. Storflor JG, Pettersen LC, Slørdal L et al. Legemidlers pakningsvedlegg ulik informasjon om like preparater. Tidsskr Nor Legeforen 2013; 133: 955-9.

5. Schwappach DL, Mülders V, Simic D et al. Is less more? Patients preferences for drug information leaflets. Pharmacoepidemiol Drug Saf 2011; 20: 987-95. 